\title{
Modern ecological state of small rivers of Western Polissia of Ukraine (on an instance of rivers Luga and Ghapa)
}

\author{
Yatsyk A. ${ }^{1}$, Pasheniuk I. ${ }^{2}$, Hopchak I. ${ }^{3}$, Basiuk T. ${ }^{4}$ \\ 1, 2 Ukrainian research institute of water-ecological problems, Inzhenernyi provulok, 4B, Kyiv, 01010, Ukraine, \\ ${ }^{3}$ National university of water economy and natural management, Soborna Str., 11, Rivne, 33028, Ukraine, ${ }^{4}$ S. \\ Demianchuk International economic-humanitarian university, Acad. S. Demia-nchuk Str., 4, Rivne, 33000, \\ Ukraine; e-mail:1, 2undiwep@gmail.com, ${ }^{3}$ gopchak_igor@ukr.net, ${ }^{4}$ tanya_basyuk@ukr.net
}

The purpose. To assess modern ecological state of small rivers of Western Polissia of Ukraine (on an instance of rivers Luga and Ghapa). Methods. Research was carried out according to regular observation on the basis of ecological classification of quality of surface waters of land and firths of Ukraine which includes a panel of hydrophysical, hydrochemical, hydrobiological and other parameters reflecting features of components of aquatic ecosystems. Results. Analysis of modern ecological state of small rivers of Western Polissia of Ukraine was carried out, and also assessment of quality of their waters on conforming classes is made. Findings of investigation were grouped in 3 blocks of parameters: salt compound of water, trophic-saprobiological (ecologicalsanitary) block, specific matters of toxic effect. Integrated (ecological) index is determined, which values establish class and category of quality of surface waters. Results of observation over quality of surface waters of rivers Luga and Ghapa testifies to their satisfactory state. Surface waters match to IInd class of quality of water (river Luga waters, transient on quality from "very good" up to "good", from "clean" up to «enough clean» on purity; river Ghapa - waters with a trend from "good" up to "satisfactory" on quality, from «enough clean» up to "poorly polluted" on purity). Excess of maximum-permissible concentration is fixed according to trophic-saprobiological parameters. It is caused by high anthropogenic load in basins of the rivers, first of all, waste interceptions of not enough cleaned waste waters. Conclusions. For assessment of ecological situation of water objects of Western Polissia and determination of main directions of water-security activity on improvement of ecological state of each water object the great value has water quality assessment of small rivers.

Key words: river, surface waters, quality of water, integrated index, ecological evaluation.

https://doi.org/10.31073/agrovisnyk201902-08

Introduction (problem). The ecological status of surface water undergoes constant changes in space and time. This is due primarily to their intense mismanagement. Surface water quality both large and small rivers depends on the pollution of their wastewater industry and utilities, as well as runoff of populated areas, industrial sites, agricultural fields. For small rivers create preconditions zone formation patterns of resource drain the water quality of major rivers. So the problem of pollution of small rivers and their Hydroecological analysis is very relevant today [1].

Early observations of the quality of surface water of small rivers is necessary for the analysis and synthesis of information on the status of water bodies, forecasting its changes and development of scientifically based recommendations for appropriate management decisions in the use and protection of water resources.

Analysis of recent research and publications of the subject. Assessing the quality of water from different positions devoted to a number of scientific research. An important contribution to the methodology of complex integrated assessment of ecological state of river basins have J. Hryb [2] and A. Yatsyk [3, 4]. Evaluation of the quality of river water and basic ways to improve the ecological state of small rivers, including River Basin Western Bug, highlights the papers, J. Molchak [5] V. Khilchevsky, M. Zabokrytska [6].

The purpose of research - assessment of the current status of small rivers of Western Polissya. Object is a surface water rivers Luga and Gapaa occurring in the Volyn region and belong to the basin. Western Bug.

Materials and methods. Assessment of the current status of surface water of small rivers Western Polissya made according to systematic observations based on environmental quality classification of surface water and estuaries Ukraine, which includes a set of hydrophysical, hydrochemical, hydrobiological and other indicators that reflect the features of the components of aquatic ecosystems. Evaluation of the quality of natural 
waters hydrochemical involves determining a number of factors: 1) physical-chemical parameters $\left(\mathrm{pH}, \mathrm{O}_{2}\right.$, biochemical oxygen demand in 5 days $\left.-\mathrm{BOD}_{5}\right) ; 2$ ) major ions $\left(\mathrm{NSO}_{3}^{-}, \mathrm{SO}_{4}{ }^{2-}, \mathrm{Cl}, \mathrm{Ca}^{2+}, \mathrm{Mg}^{2+}, \mathrm{Na}^{+}, \mathrm{K}^{+}\right)$ions and amount; 3) nutrients $\left(\mathrm{NH}^{4}+, \mathrm{NO}_{-}-, \mathrm{NO}_{3}{ }^{-}, \mathrm{N}, \mathrm{PO}_{4}{ }^{3-}, \mathrm{P}, \mathrm{Si}\right)$; 4) trace elements (Fe, $\left.\mathrm{Cu}, \mathrm{Zn}, \mathrm{Mn}\right)$; 5) specific pollutants (surfactants, phenols, petroleum products).

Output according to "Methods of ecological assessment of surface water quality by appropriate categories" [4] were grouped into three blocks of indicators:

1) the salinity of water $\left(I_{1}\right)$;

2) tropho-saprobiological (ecological and sanitary) block $\left(\mathrm{I}_{2}\right)$;

3) specific toxic substances $\left(I_{3}\right)$.

Based on the values of block indexes, the integral (ecological) index $\left(\mathrm{I}_{\mathrm{E}}\right)$ is calculated according to the surface water quality standards. In accordance with the values of which establishes a class and category of quality, which characterizes a certain quality of water $[3,4]$.

Modern studies of the quality of water in the Luga and Gapaa rivers are based on the results of observations of the State Environmental Inspectorate in the Volyn region on the hydrochemical indicators of water in 2017 [9].

The results of research. West Polissya basins in recent decades undergone significant changes especially. Changes in the ecological condition of river basins and the formation conditions of surface water quality of small rivers Polissya occurred due to the growing influence of anthropogenic impact on their pools, and the lack of spatial development boundaries pools [7].

Rivers that are investigated are right tributaries of. Western Bug. Meadows takes place within Lokachi, Ivanychiv and Vladimir-Volynareas and Gapaa - Lyubomlsky district, Volyn region, the length. Meadows is about $93 \mathrm{~km}$ and g. Gapaa - $14 \mathrm{~km}$; pool area - under 1,348 sq km and $140 \mathrm{sq} \mathrm{km} \mathrm{[5-8,} \mathrm{10].}$

Determining the ecological status of surface water rivers studied, conducted on the approved areas of state monitoring of water quality [9]: g. Meadows - point s. P'yatydni (6 km from the mouth of the river); g. Gapa - point s. P'yatydni (2 km from the mouth of the river below the lake Jagodinsk).The results of the environmental assessment of surface water quality of rivers Luga and Gapa are given in table. 1.

Block indexes salt content $\left(l_{1}\right)$. Based on studies of rivers Luga and Gapa for salt content of water determined that mineralization reflects the geographical conditions of the drain and ranged from $316,5 \mathrm{mg} / \mathrm{dm}^{3} \mathrm{to}$ $481,8 \mathrm{mg} / \mathrm{dm}^{3}$. Therefore, river water salinity meet criterion 1 category and class of water quality is "fresh water."

Chlorides and sulfates due to its high solubility present in all natural waters. The value of the content of chloride in surface waters of rivers ranged from $23,9 \mathrm{mg} / \mathrm{dm}^{3}$ to $26,4 \mathrm{mg} / \mathrm{dm}^{3}$, which in the normal $\left(350 \mathrm{mg} / \mathrm{dm}^{3}\right)$. Water quality and meet the class. Value sulfate content was in the range of $18,9 \mathrm{mg} / \mathrm{dm}^{3}$ to $54,7 \mathrm{mg} / \mathrm{dm}^{3}$ (ecological optimum - $500 \mathrm{mg} / \mathrm{dm}^{3}$ ). Surface water quality and meets class "excellent" as "very clean" for purity.

Overall figures salt block within the MAC for fishery water use. Surface water rivers belong to the class and water quality ( "excellent" - "very good" in the class "very clean" - "clean" for purity). 
Table 1 Environmental assessment of surface water quality of small rivers in Western Polissya (2017)

\begin{tabular}{|c|c|c|c|c|c|}
\hline \multirow{2}{*}{ № } & \multirow{2}{*}{ Indicator } & \multicolumn{2}{|c|}{ river Luga } & \multicolumn{2}{|c|}{ river Gapa } \\
\hline & & value & category & value & category \\
\hline \multicolumn{6}{|c|}{ Block indexes salt content } \\
\hline 1 & the dry residue, $\mathrm{mg} / \mathrm{dm}^{3}$ & 481,8 & 1 & 316,5 & 1 \\
\hline 2 & chlorides & 23,9 & 2 & 26,4 & 2 \\
\hline \multirow[t]{3}{*}{3} & Sulfates & 18,9 & 1 & 54,7 & 2 \\
\hline & $I_{1}$ & 1,3 & 1 & 1,7 & 2 \\
\hline & Class of water quality & $A N D$ & & II & \\
\hline \multicolumn{6}{|c|}{ Block trophic and saprobiological (ecological and sanitary) indicators } \\
\hline 4 & suspended solids, $\mathrm{mg} / \mathrm{dm}^{3}$ & 8,5 & 2 & 12 & 3 \\
\hline 5 & transparency, see & 27,5 & 6 & 27 & 6 \\
\hline 6 & $\mathrm{pH}$ & 7,4 & 1 & 6,5 & 3 \\
\hline 7 & ammonia nitrogen, $\mathrm{mg} / \mathrm{dm}^{3}$ & 0,381 & 4 & 0,689 & 5 \\
\hline 8 & nitrogen nitrite, $\mathrm{mg} / \mathrm{dm}^{3}$ & 0,042 & 5 & 0,023 & 5 \\
\hline 9 & nitrogen nitrate, $\mathrm{mg} / \mathrm{dm}^{3}$ & 2 & 6 & 1,18 & 6 \\
\hline 10 & dissolved oxygen, $\mathrm{mg} / \mathrm{dm}^{3}$ & 7,08 & 3 & 7 & 4 \\
\hline 11 & cod, $\mathrm{mg} \mathrm{dm}{ }^{3}$ & 7,82 & 1 & 8,26 & 1 \\
\hline \multirow[t]{3}{*}{12} & $\mathrm{BOD}_{5}, \mathrm{mg} / \mathrm{dm}^{3}$ & 3,61 & 4 & 4,45 & 5 \\
\hline & $I_{2}$ & 3,6 & 4 & 4,2 & 4 \\
\hline & Class of water quality & III & & III & \\
\hline \multicolumn{6}{|c|}{ Block specific indicators toxic effects } \\
\hline 13 & Iron overall, mg/dm ${ }^{3}$ & 0,28 & 4 & 0,678 & 5 \\
\hline \multirow[t]{3}{*}{14} & Manganese, $\mathrm{mg} / \mathrm{dm}^{3}$ & 0,023 & 2 & 0,033 & 3 \\
\hline & $I_{3}$ & 3 & 3 & 4 & 4 \\
\hline & Class of water quality & II & & III & \\
\hline \multicolumn{6}{|c|}{ The integrated ecological index } \\
\hline & $I_{E}$ & 2,6 & 3 & 3,3 & 3 \\
\hline & Class of water quality & II & & II & \\
\hline
\end{tabular}

Block trophic and saprobiological (ecological and sanitary) indicators $\left(I_{2}\right)$. In terms of unit surface waters of rivers Luga and Gapa belonging to category 4 class III water quality. It should be noted that the greatest effect on the block index $I_{2}$ were indicators such as transparency and nitrate nitrogen content. Surface water according to figures belonging to category 6 class IV quality ( "bad" for the class, "dirty" for purity).

Block specific indicators toxic effects $\left(I_{3}\right)$. As to block specific substances toxic action is in river basins that were investigated, monitored the presence of only the total iron and manganese. Therefore, the environmental assessment for this unit can be considered tentative. Total iron values recorded within $0,28-0,678$ $\mathrm{mg} / \mathrm{dm}^{3}$ manganese $-0,023-0,033 \mathrm{mg} / \mathrm{dm}^{3}$. The water quality of the river by this unit corresponds to class III.

Joint Environmental Assessment $\left(l_{E}\right)$. For the final integrated environmental index ( $\left.I_{E}\right)$ surface water rivers belong to the second class of water quality and characterized as follows (table. 2): r. Luga - water transition in quality from "very good" to "good" from "clean" to "very clean" purity; r. Gapa - water from the trend approaching from "good" to "satisfactory" for quality from "very friendly" to "slightly contaminated" with purity. 
Table 2 Joint environmental assessment of surface water quality of small rivers in Western Polissya 2017

\begin{tabular}{|l|c|c|c|c|c|c|c|c|}
\hline \multirow{2}{*}{ Indicator } & \multicolumn{4}{c|}{ r. Luga } & \multicolumn{4}{c|}{ r. Gapa } \\
\cline { 2 - 10 } & $\mathrm{I}_{1}$ & $\mathrm{I}_{2}$ & $\mathrm{I}_{3}$ & $\mathrm{I}_{\mathrm{E}}$ & $\mathrm{I}_{1}$ & $\mathrm{I}_{2}$ & $\mathrm{I}_{3}$ & $\mathrm{I}_{\mathrm{E}}$ \\
\hline Size & 1.3 & 3.6 & 3 & 2.6 & 1.7 & 4.2 & 4 & 3.3 \\
\hline Category & 1 & 4 & 3 & 3 & 2 & 4 & 4 & 3 \\
\hline Subkatehoriya & $1(2)$ & $3-4$ & 3 & $2-3$ & $1-2$ & 4 & 4 & $3(4)$ \\
\hline Class of water quality & $\mathrm{I}$ & $\mathrm{III}$ & $\mathrm{II}$ & $\mathrm{II}$ & $\mathrm{II}$ & III & III & II \\
\hline
\end{tabular}

\section{Conclusions}

The results of observations on the quality state of surface waters of the Luga and Gapa rivers indicate their satisfactory condition. Waters meet the 2nd grade water quality. Excess MPC recorded on trophic and saprobiological indicators. This is due to the high anthropogenic pressure in the river basins, primarily discharges of insufficiently treated wastewater.

Determining the quality of water for small rivers is important for assessing the ecological situation of water objects in the Western Polissya area, the main directions of water protection activities for the improvement of the ecological status of each water facility, as well as the establishment of environmental water quality standards.

\section{Bibliography}

1. Yatsyk A.V. (1997). Ekolohycheskye osnovy ratsyonalnoho vodopolzovanyia [Ecological basis of rational water use]. Kiev: Heneza. 640 p. [in Russian].

2. Hryb V., Klymenko M., Sondak V. (1999). Vidnovna hidroekolohiia porushenykh richkovykh ta ozernykh system (hidrokhimiia, hidrolohiia, upravlinnia) [Restorative hydroecology of disturbed river and lake systems (hydrochemistry, hydrology, management)]. Navch. posib. T. 1. - Rivne: Rivnen. derzh. tekhn. un-t. 348 p. [in Ukrainian].

3. Metodyka vstanovlennia i vykorystannia ekolohichnykh normatyviv yakosti poverkhnevykh vod sushi ta estuariiv Ukrainy (2001). [Method of installation and use of environmental regulations as surface water and estuaries Ukraine]. Kiev. 48 p. [in Ukrainian].

4. Romanenko V., Zhukinskyi V., Oksiiuk O., Yatsyk A. (1998). Metodyka ekolohichnoi otsinky yakosti poverkhnevykh vod za vidpovidnymy katehoriiamy [Methodology of ecological assessment of surface water quality according to the relevant categories] Kiev. 28 p. [in Ukrainian].

5. Molchak Y., Mihas R. (1999). Richky Volyni [Volyn rivers]. Lutsk: Nadstyria. 176 p. [in Ukrainian].

6. Zabokrytska M., Khilchevskyi V., Manchenko A. (2006) Hidroekolohichnyi stan baseinu Zakhidnoho Buhu na terytorii Ukrainy [Hydroecological state of the basin of the Western Bug on the territory of Ukraine]. Kiev : Nika. 184 p. [in Ukrainian].

7. Klymenko O., Statnyk I. (2012). Metodolohiia pokrashchennia ekolohichnoho stanu richok Zakhidnoho Polissia (na prykladi r. Horyn): monohrafiia [Methodology for improving the ecological status of the rivers of Western Polissya (for example, the Gorin River): monograph]. Rivne : NUVHP. 206 s. [in Ukrainian].

8. Yatsyk A. za red. (1991). Mali richky Ukrainy: dovidnyk [Small rivers of Ukraine: directory]. Kiev : Urozhai. 296

s. [in Ukrainian].

9. Informatsiinyi biuleten pro yakisnyi stan poverkhnevykh vod baseinu richky Zakhidnyi Buh u 2017 rotsi (2018). [Newsletter on the qualitative state of surface waters of the Western Bug River basin in 2017]. Lutsk. 50 s. [in Ukrainian].

10. Yatsyk A.V., Pasheniuk I., Hopchak I., Basiuk T. (2017). Ekolohichna otsinka suchasnoho stanu yakosti vody richky Luha [Environmental assessment of the current state of water quality in the Luga]. Zbirka dopovidei Mizhnarodnoho konhresu «ETEVK-2017». Chornomorsk. S. 182-186. [in Ukrainian].

11. Rahaman M.M., Mizanur M., Varis O. (2005). Integrated Water resources management: evolution, prospects and future challenges. Sustainability: Science, Practice, \& Policy. V. 1. Is. 1. P. $15-21$. 